\title{
CMOS Development and Optimization, Scaling Issue and Replacement with High-k Material for Future Microelectronics
}

\author{
Davinder Rathee \\ Dept of ECE \\ Guru Jambeshwer university \\ Hisar
}

\author{
Mukesh Kumar \\ Electronics Science Department \\ Kurukshetra University \\ Kurukshetra
}

\author{
Sandeep K. Arya \\ Department of ECE \\ Guru Jameshwer University, \\ Hisar
}

\begin{abstract}
:
The development and optimization of Silicon technology has been guided by CMOS scaling theory [1] and predications made by Semiconductor Industry (SIA) in the International Technology Roadmap for Semiconductor (ITRS). With the trend of scaling down of Complementary Metal Oxide Semiconductor (CMOS) transistor as Moore's Law [2] requires replacement of conventional silicon dioxide layer with the higher permittivity material for gate dielectric. As the silicon industry moves to $32 \mathrm{~nm}$ technology node and beyond complaints like leakage and power dissipation dominates. Managing such issues are crucial factors for reliable high speed operation and chip design. Although scaling will continue for couple of decades but device geometries reaches to atomic size and limitation of quantum mechanical physical boundaries. To address these problems there is need of innovation in material science \& en gineering, device structure, and new nano devices based on different principle of physics. Here we have elaborated about scaling issues and alternate high-k dielectric for Metal Oxide Semiconductor Field Effect Transistor (MOSFET). Introducing a high-k material may replace today's silicon dioxide technology and can also provide extendibility over several generations. $\mathrm{C}-\mathrm{V}$ analyses have been studied for various MOS capacitor with conventional $\mathrm{SiO}_{2}$ and also with high-k material like $\mathrm{Gd}_{2} \mathrm{O}_{3}$, $\mathrm{ZrO}_{2}, \mathrm{HfO}_{2}$, and $\mathrm{TiO}_{2}$.
\end{abstract}

Key words: Scaling, High-k, Material oxides

\section{INTRODUCTION:}

The fundamental building blocks for all computer chipstransistors - have tracked with Moore's Law for forty years. The transistors manufactured today are 25 times faster than and occupy less than $1 \%$ of the area of those builds four decades ago. In the past four decades the downsizing/scaling of MOSFET results to smaller device in smaller area, consumption of less power, and decrease in cost per transistor per function cost of integrated circuit.

\subsection{SCALING ISSUES OF CMOS CIRCUITS:}

The constraint for technology to scale insist that the total power consumption per unit area remains constant which means that as density of the circuitry in a technology increases, the amount of cooling requirement for the circuit remains constant- if this was allowed to increase after some point, the circuit would melts [1]. Many limitations for the down scaling have been proposed in the literature [1,3] Table1. Unfortunately the thickness gate silicon dioxide reaches its thinnest limit. Now further scaling oxide layer is not capable to maintain insulating property, since direct tunneling dominates the leakage current further down scaling leads several physical and technological limitations.

\subsection{SCALING PREDICATIONS AND PRESENT ERA:}

Most important research paper which specifies the research required to continue rapid development in semiconductor industry is International Technology Roadmap for Semiconductor (ITRS. The scaling dimensions have reduced to a factor 1000 during last 40 years (fig-1). The further reduction in gate insulator thickness leads to short channel effects, drainvoltage-induced barrier lowering, and increase to leakage current. ITRS says that the silicon technology will continue to shrink with its historical rate of predictions with Moore Law for decades [4]. Every other year new assessment is published and reduction in gate length has been observed to even faster than the predication fig- 1 and table- 2 . In 1958, the integrated circuit was born when Jack Kilby at Texas Instrument. The research in this field saw the evolution of the (MOSFET) in 1960and the invention of Complementary Metal Oxide Semiconductor (CMOS) transistors in 1963.In 1970 because of short channel effects and the resolution of the optical lithography limit for channel was considered to be one micrometer.

Table-1 The scaling rule for de vice parameter by a unit less scaling factor á with possible solution for smarter, faster, lower power dissipation, and

\begin{tabular}{|l|l|l|l|}
\hline Microelectronics parameter & $\begin{array}{l}\text { Scaling } \\
\text { Factor }\end{array}$ & Limiting factor & Solutions \\
\hline Voltage $\mathbf{V}_{\text {dd }}$ & $1 / \hat{a}$ & $\begin{array}{l}\text { Thermal Voltage/quantum } \\
\text { confinement }\end{array}$ & Low operating temp. \\
\hline Electric Field & 1 & & \\
\hline Channel Length L & $1 / \hat{a}$ & Lithography & Double Gate structure \\
\hline
\end{tabular}




\begin{tabular}{|c|c|c|c|}
\hline Drain Current & $1 / \hat{a}$ & Punch through & (DG FET) \\
\hline $\begin{array}{l}\text { Gate capacitance per unit area, } \\
C_{o x}=\varepsilon_{o x} / D\end{array}$ & $\hat{\mathrm{a}}$ & \multirow{4}{*}{$\begin{array}{l}\text { Physical thickness } \\
\text { Limit } \\
\text { Non Scalabilities }\end{array}$} & \multirow{4}{*}{$\begin{array}{l}\text { Oxynitride /high-K } \\
\text { Atomic layer } \\
\text { deposition } \\
\text { (ALD) }\end{array}$} \\
\hline Gate area, $\mathbf{A}_{\mathrm{g}}=\mathbf{L} * \mathbf{W}$ & $1 / \hat{a}^{2}$ & & \\
\hline Gate capacitance $C_{g}=\varepsilon_{0} A / d$ & $1 / \hat{a}$ & & \\
\hline Parasitic capacitance $C_{x}$ & $1 / \hat{a}$ & & \\
\hline $\begin{array}{l}\text { Carrier density in channel, } Q_{o n} \\
=C_{o} V_{g s} \\
\text { Channel resistance } R_{o n}= \\
1 / W Q_{o n}\end{array}$ & $\begin{array}{l}1 \\
1\end{array}$ & & \multirow[t]{2}{*}{$\begin{array}{l}\text { High mobility } \\
\text { material/strained } \\
\text { devices/ } \\
\text { Chemical process }\end{array}$} \\
\hline Gate propagation delay $T_{p d}$ & 1/â & Non Scalable $V_{d d}$ & \\
\hline $\begin{array}{l}\text { Maximum operating } \\
\text { frequency, } \mathrm{f}_{\mathrm{o}}\end{array}$ & $\hat{\mathrm{a}}^{2}$ & $\begin{array}{l}\text { Parasitic cap acitance, EMI, } \\
\text { interconnect } R \text { \& } C\end{array}$ & $\begin{array}{l}\text { Low K-insulator } \\
\text { Copper }\end{array}$ \\
\hline S aturation current, $\mathbf{I}_{\mathrm{dss}}$ & $1 / \hat{a}$ & \multirow{6}{*}{$\begin{array}{l}\text { Gate leakage current } \\
\text { Frequency of transistor } \\
\text { Over heating }\end{array}$} & \multirow{6}{*}{$\begin{array}{l}\text { Smart sy stem power } \\
\text { management } \\
\text { Physical thicker gate } \\
\text { dielectric } \\
\text { High - k-dielectric }\end{array}$} \\
\hline Current density, J & $\hat{\mathrm{a}}$ & & \\
\hline $\begin{array}{l}\text { S witching energy per gate } \\
E_{\mathrm{g}}=\mathrm{I} \mathrm{C}_{\mathrm{g}}\left(\mathrm{V}_{\mathrm{DD}}\right)^{2} / 2\end{array}$ & $1 / \hat{\mathrm{a}}^{3}$ & & \\
\hline $\begin{array}{l}\text { Power dissipation per gate, } P_{g} \\
P_{g}=P_{g s}+P_{g d} \text { Both } P_{g s} \text { an } \mathbf{P} P_{g d} \\
\text { are scaled by }\end{array}$ & $1 / \hat{a}^{2}$ & & \\
\hline $\begin{array}{l}\text { Power dissipation per unit area } \\
\mathbf{P}_{\mathrm{a}}=\mathbf{P}_{\mathrm{g}} / \mathbf{A}_{\mathrm{g}} \text { is scaled by } \alpha^{2} / \boldsymbol{\beta}^{2}\end{array}$ & 1 & & \\
\hline $\begin{array}{l}\text { Power speed product, } \\
=P_{g} T_{d}\end{array}$ & $1 / \hat{a}^{3}$ & & \\
\hline Transistor per chip $n$ & $\hat{a}^{2}$ & $\begin{array}{l}\text { Yielding, complexity in } \\
\text { interconnection }\end{array}$ & $\begin{array}{l}\text { Serial signal } \\
\text { communication }\end{array}$ \\
\hline
\end{tabular}

A general scaling rule of MOS devices

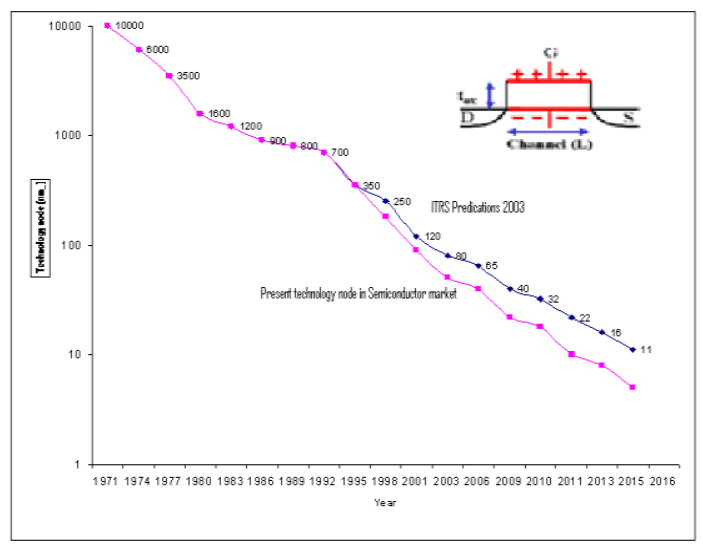

Fig-1 MOS channel length scaling and predication made by IT RS 2003 (blue line) and physical channel length (pink line)

In 1980 limitations were increased source/drain resistance, direct tunneling through gate oxide and dopant fluctuation in Short channels results to half to quarter micron [5]. While in 1990, $100 \mathrm{~nm}$ was thought to be limit because of some physical parameter and increase of fundamental atomistic vibrations.

\subsection{CURRENT ISS UES IN SCALING OF S UB-32 NM DEVICES}

The ITRS is most important industrial strategy paper for semiconductor devices \& technology towards high performance and lower cost. ITRS is organized by the Semiconductor association of Europe, Japan, Korea, Taiwan and the USA. The representative from leading semiconductor 
companies around the world agrees on several issues one of them was phy sical gate len gth of microprocessor [13]. Currently the "International Technology Working Groups" (ITWG) USA, is responsible for technologies and methodologies used for future area of research. The "National Technology Roadmap of semiconductor (NTRS) and ITRS have scaling predication from 100 components per IC in 1965 to 15 billion in the current state of art. There are less gain in device performance i.e power consumption, short channel effects and parasitic capacitance as scaling goes further below sub-100 nm [5,14]. In 2007 the use of high-K dielectrics is introduced for the first time, to address gate leakage issues.

The performance of MOS transistor below $30 \mathrm{~nm}$ in still below satisfactory and also the characteristics across wafer is also of great concern. Because of downscaling the gate length and gate oxide thickness decreased only 100, supply voltage decreased by factor 10, chip area increased by 10 and power dissipation increased by $10^{5}$, which may not increased under ideal scaling. The major difficulties are tremendous cost of lithography and in developing new technologies [10]. In table-2 column 1 shows technology node which means the smallest poly-Si/metal gate length and column 2 shows expected starting year. It is being noted that neither $22 \mathrm{~nm}$ nor $16 \mathrm{~nm}$ numerical value appearing value in the corresponding ITRS parameter sets. The device less than $10 \mathrm{~nm}$ gate length would be extremely sensitive to the device physical dimensions and variations in material composition. The literature clearly states that $0.1 \mathrm{~nm}$ oxide, a 0.1 increase in the root-mean-square (RMS) interface roughness can lead to 10 fold increase in gate leakage current [12-13]. So growth of such films must be precisely controlled on atomic scales. Also searching for ultra thin gate dielectric need to be investigated and then integrated with silicon technology. Due recent economical depression all the semiconductor companies except Intel reduced the budget for R \& D. In future there is possibility on more delay in the trend of gate-length shrinkage, Equivalent gate oxide thickness and the depth of junction. In this review paper recent development and the progress of the ultra thin gate dielectric material is summarize. Presently sub-100 nm MOS transistor is in production and $6 \mathrm{~nm}$ gate length is under research.fig-3 [6]. Recently 2009-2010 Intel corporation manufacturing transistors have set a record $I_{\text {on }} / I_{\text {off }}$ characteristic with different metal gates and high K-dielectric material.

Table-2 Gate dielectric layer technology requirement [8-10].

\begin{tabular}{|c|c|c|c|c|c|c|}
\hline \multirow{2}{*}{$\begin{array}{l}\text { Technology } \\
\text { Node } \\
\text { (nm) }\end{array}$} & \multirow{2}{*}{$\begin{array}{c}\text { Starting } \\
\text { year }\end{array}$} & \multicolumn{3}{|c|}{ ITRS updates } & \multirow{2}{*}{$\begin{array}{l}\mathrm{T}_{\mathrm{inv}} \\
(\mathrm{nm})\end{array}$} & \multirow[t]{2}{*}{ EOT(nm) } \\
\hline & & Years & Half pitch (nm) & Physical length(nm) & & \\
\hline 45 & 2007 & $\begin{array}{l}2007 \\
2008\end{array}$ & $\begin{array}{l}68 \\
59\end{array}$ & $\begin{array}{l}32 \\
29\end{array}$ & 14 & 1.0 \\
\hline 35 & 2009 & $\begin{array}{l}2009 \\
2010\end{array}$ & $\begin{array}{l}52 \\
45\end{array}$ & $\begin{array}{l}27 \\
24\end{array}$ & 12 & 0.8 \\
\hline 22 & $\begin{array}{l}2011 \\
2012\end{array}$ & $\begin{array}{l}2011 \\
2012\end{array}$ & $\begin{array}{l}40 \\
36\end{array}$ & $\begin{array}{l}22 \\
20\end{array}$ & 10 & 0.6 \\
\hline 16 & $\begin{array}{l}2013 \\
2014\end{array}$ & $\begin{array}{l}2013 \\
2014\end{array}$ & $\begin{array}{l}32 \\
29\end{array}$ & $\begin{array}{l}18 \\
16\end{array}$ & $?$ & $?$ \\
\hline
\end{tabular}

*EOT- equivalent oxide thickness

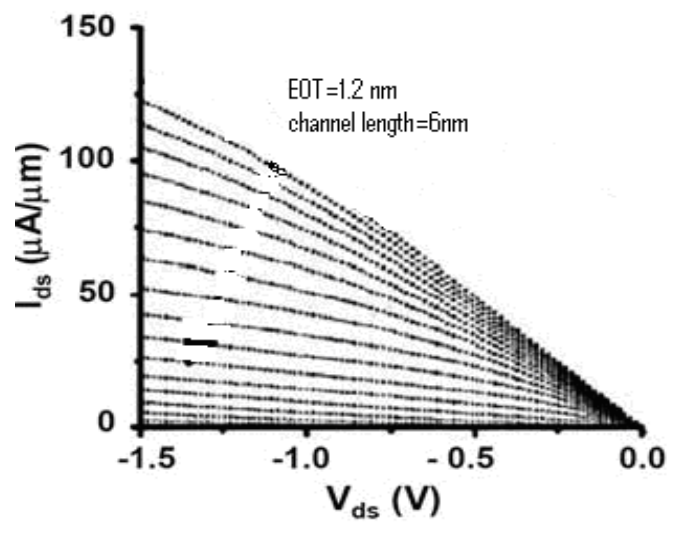

Fig-3. Experimental $6 \mathrm{~nm}$ MOS transistor with 1.2-nm thick $\mathrm{SiO}_{2}$ gate still shows a switch gain Shows the current-voltage characteristics of this transistor [3,5].

\section{SCALING LIMIT OF S IO}

Thirty years ago oxide thickness was $100 \mathrm{~nm}$ and now it is 0.7 $\mathrm{nm}$ in production while direct tunneling limit of conventional oxide $\left(\mathrm{SiO}_{2}\right)$ was $3 \mathrm{~nm}$. The gate oxide up to $0.7 \AA$ has been obtained having only two atomic layer of $\mathrm{SiO}_{2}$. Further Scaling is difficult [10]. One of the most convincing experiment which demonstrated that $3 \mathrm{~nm}$ is fundamental limit $[11,15]$. Using the scanning transmission electron microscope (STEM) probes and through detailed 


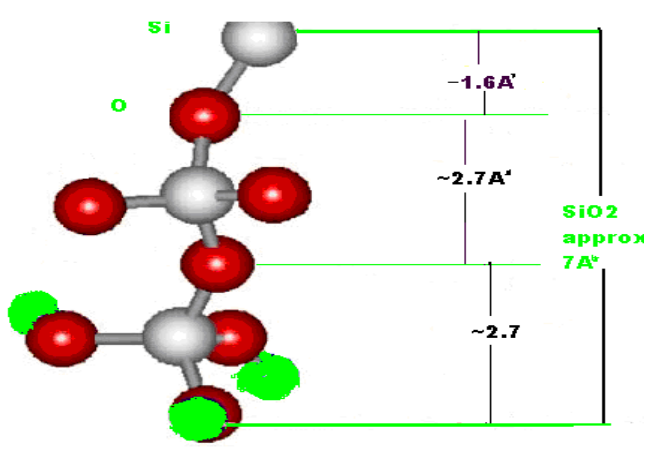

Fig-5 Bonding structu re of $\mathrm{SiO}_{2}$

Electron Loss Spectroscopy (EELS) measurements they studied that device structure and chemical composition of the oxide layer as thin as $0.7-1.2 \mathrm{~nm}$. In the literature work, the local energy gap was given by separation between highest occupy and lowest occupied states. They found that to ensure bulk like bonding for monolayer minimum three or four monolayer of $\mathrm{SiO} 2$ were needed. This is the first phy sical dimension of atomic level. EELS show that the $\mathrm{SiO} 2$ thickness must have two layers to show a full gap of $8.9 \mathrm{eV}$ [11]. The few unscalable parameter interface thickness and trap cross section challenges gate dielectric reliability. When oxide is in nanometer even small non-uniformity either in chemical composition or even at surface fluctuation device characteristics 10 fold [12,16] . As scaling fall under two main categories high performance (HP) devices and low performance (LP) devices. HP is used for

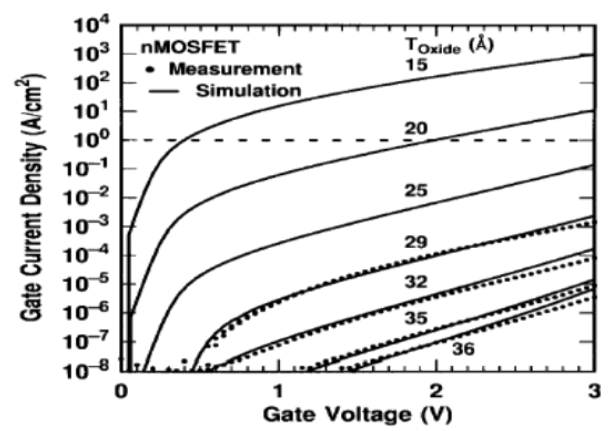

\subsection{ALTERNATE DIELECTRIC MATERIAL:}

The choice of thicker class of materials, known as "high-k," may replace today's silicon dioxide technology not for $45 \mathrm{~nm}$ or 32 $\mathrm{nm}$ but can also be scaled to the end-of-the roadmap technology nodes. Typically for high- $\mathrm{k}$ materials under investigation are $\mathrm{Al}_{2} \mathrm{O}_{3}$ [22-26], $\mathrm{ZrO}_{2}$ [27-29], $\mathrm{HfO}_{2}$ [30], $\mathrm{Ta}_{2} \mathrm{O}_{5}, \mathrm{TiO}_{2}$ [31-33], $\mathrm{Er}_{2} \mathrm{O}_{3}, \mathrm{La}_{2} \mathrm{O}_{3}, \mathrm{Pr}_{2} \mathrm{O}_{3}, \mathrm{Gd}_{2} \mathrm{O}_{3}[34], \mathrm{Y}_{2} \mathrm{O}_{3}, \mathrm{CeO}_{2}$ etc. and some of their silicates such as $\mathrm{Zr}_{\mathrm{x}} \mathrm{Si}_{1-\mathrm{x}} \mathrm{Oy}, \mathrm{Hf}_{\mathrm{x}} \mathrm{Si}_{1-\mathrm{x}} \mathrm{Oy}, \mathrm{Al}_{\mathrm{x}} \mathrm{Zr}_{1-\mathrm{x}} \mathrm{O}_{2}$ etc. The key guideline for Research and development are given in fig-8(a).

\subsection{CHOICE OF HIGH-K MATERIAL:}

We may classify them in three main classes, class 1 needs, three basic properties with dielectric constant range 15-25. B and gap about $5 \mathrm{eV}$ behave as insulator. Ferromagnetic materials are less desirable because of their nonlinear electrical response. Polarization of dielectric will have both electronic and ionic devices like desktop and server application so high leakage is acceptable while for LP devices like mobile main goal is minimization of power consumption for battery life, this requirement can be fulfilled by introduction of some novel gate dielectric [13,17]. According to Lo et al. reduction in oxide thickness from $2 \mathrm{~nm}$ to $1.5 \mathrm{~nm}$ produces leakage current of two order of magnitude [18]. Such values would not be acceptable for devices which operated by lower voltages. As shown in fig-6 the leakage current density $100 \mathrm{~A} / \mathrm{cm} 2$ at $1.5 \mathrm{~V}$ for $1.5 \mathrm{~nm}$ oxide thickness is undesirable for low power application. Also leakage current increases exponentially as oxide thickness reduced linearly which is one of the major criteria for future CMOS technology [18]. As the oxide thickness reaches the atomic level further scaling is impossible in nanometer range. Also supply voltage of 1.1 and oxide thickness of $0.9 \mathrm{~nm}$ devices does not perform reliably because of large oxide field with further decrease in supply voltage. This happens because part of the applied voltage drops in inversion layer of the channel. So alternative to continue to scaling to $\mathrm{SiO} 2$, recent effort has focused on development of alternative dielectric material, whose $\mathrm{Si}$ interface properties match the high quality of $\mathrm{Si} / \mathrm{SiO} 2$ interface. [19-21]. So far the traditional approach followed to scale the gate dielectric has been reduce tox to increase Cox. Where $\mathrm{Cox}=\mathrm{K} \mathrm{SiO} 2 \varepsilon 0$ / tox where $\mathrm{K} \mathrm{SiO} 2=3.9$. To reduce main problem of tunneling current scaling forces towards high$\mathrm{K}$ dielectric approach relative to $\mathrm{SiO} 2$ to increase physical thickness of film ( $\mathrm{t}$ high-k) with higher values gate capacitance. $(\mathrm{C}$ high-k $)=(\mathrm{K}$ high-k) $\varepsilon 0 /$ (t high-k $)$.

\begin{tabular}{l}
\hline - High gate leakage current \\
- Thermal stability \\
- Interfacial layer formation \\
- Channel mobility \\
- High-k stability with poly- \\
- Si-Gates \\
Fig-8(a) R\&D issue for high-k
\end{tabular}

components. Because of large -ionic polarization defect formation is easier. Class II The dielectric microstructure may be of amorphous, polycrystalline or epitaxial. However it is important that dielectric should be

- permittivity, band gap, and band alignment to silicon

- Thermody namic stability

- Film morphology

- Interface quality

- Compatibility with material used in CMOS

- Low leakage current density $\left(<1 \quad \mathrm{~A} / \mathrm{cm}^{2}\right.$ @ VGS=VDD)

- Reliability comparable to $\mathrm{SiO}_{2}$

- Low fixed oxide charge / interface state density < $10^{11} \mathrm{~cm}^{-2}$

- Equivalent oxide thickness (EOT) - 10 to $15 \AA$

- Large band gap $(>6 \mathrm{eV}) /$ suitable band off-sets

- High dielectric constant $\left(10<\sum r<50\right)$ 


\section{8(b)selection criteria for high-k}

\section{Fig-6 Oxi de leakage current vs oxi de thickness [18]}

non-reactive with $\mathrm{Si}$ and with gate contacts. Class III needs to relate to performance. The dislocation defects, grain bound aries or point defects related to electrode rou ghness results to leakage current [36].The ferroelectric class of material having $\mathrm{K}$ range 100 to 1000 has been pursued for 1GB and beyond dynamic random access memories (DRAM) storage capacitors [37]. Because of composite structure and stability with adjoining layers can't be used for transistor gate dielectric. Many high-K materials consist of oxide and alloys shown in fig-7 include column 3B material $\mathrm{Y} 2 \mathrm{O} 3$, La2O3, column 4B material $\mathrm{ZrO}$, \& HfO2, Column 5B material Ta2O3 have and also approximately inverse relation between band gap and static dielectric constant obeyed by a number of representative high-K dielectrics. It should be noticed that offset energy difference between oxide and silicon valance bonds $\triangle \mathrm{Ev}$, has same importance as $\triangle \mathrm{Ec}$ for the functioning of oxide in CMOS application. The value of $\Delta \mathrm{Ev}$ can be obtained by knowing the value of $\Delta \mathrm{Ec}$ from the equation $\mathrm{Ego}-(\Delta \mathrm{Ec}+\mathrm{EgSi})$, where Ego and $\mathrm{EgSi}$ are the band gap values of the oxide and silicon respectively.It has also been observed that d-electron metal transferred nearly its entire valance electron to the oxy gen atom, so increased iconicity and have polarization.

The natural vibration frequency associated with metal oxygen bond lowered and highly desirable in microelectronic applications. It is the purpose of the remaining paper to explain complex issues for the use of high- $\mathrm{K}$ material for gate dielectric applications and also to provide an update review on $\mathrm{Hfo}_{2}, \mathrm{ZrO}_{2}, \mathrm{TiO}_{2}, \mathrm{Gd}_{2} \mathrm{O}_{3}$ and some another high-K dielectric material shown in table-4.Aluminum oxide $\left(\mathrm{Al}_{2} \mathrm{O}_{3}\right)$ having $\mathrm{k}$ value of 10 having problem of large fixed charge and interface trap density hence does not meet our future requirement [39-44]. Lanthanum oxide $\left(\mathrm{La}_{2} \mathrm{O}_{3}\right)$ and Lanthanum aluminum oxide (LaAlO 3 ) having dielectric constant $\sim 30$ and band gap $\sim 6 \mathrm{eV}$ have thermal stability with temperature up to $850{ }^{\circ} \mathrm{C}$ with amorphous nature and main problem of moisture absorption.[4546]. $\mathrm{TiO} 2$ have lowest crystalline temperature of about $400^{\circ} \mathrm{C}$ for CMOS technology. Problems of fringing field can lower the source channel potential barrier and the threshold voltage [3536].

Yttrium oxide (Y2O3) has problem of high interface density $>1012 \mathrm{eV}-1 \mathrm{~cm}-2$, low cry stalline temperature, and formation of silicide and silicate [47]. The leakage current of $\mathrm{ZrO} 2$ and $\mathrm{HfO} 2$ found to be 4-5 order of magnitude lower than $\mathrm{SiO} 2$ of equivalent gate oxide thickness. HfO2 films behave reported quite similar to $\mathrm{ZrO} 2$ because of similar fabrication chemistry and material properties. Hafina \& Zirconia are less stable then their silicates, so Hafnium and Zirconium silicate films were examined for electrical properties. The films were prepared by plasma enhanced Chemical Vapor deposition (PECVD) method. The samples having a metal insulator semiconductor structure were examined. The permittivity value was found 7 double of $\mathrm{SiO} 2$ and dielectric film operated at $10 \mathrm{MV} / \mathrm{Cm}$. Conduction band offset of $\mathrm{ZrO} 2$ may be $0.8 \mathrm{t} 01.2 \mathrm{eV}$ which is too low for MOS gate dielectric. While oxinitride having higher dielectric and stability values with slightly poor characteristics can be used down $25 \mathrm{~nm}$ technology node. Among the rare earth oxide Gd2O3 Gadolinium oxide has various features listed in table-3 and table-4. Verify that it can be used as high-K applications. The leakage current density of $\mathrm{Gd} 2 \mathrm{O} 3$ films decreased for $\mathrm{RTA}$ ( rapid thermal annealing) in $\mathrm{N} 2$ and increased in $\mathrm{O} 2$. The interface and structure of the $\mathrm{Gd} 2 \mathrm{O} 3 / \mathrm{Si}$ was amorphous and both cubic and monoclinic phases were well oriented. Further research work is required to improve electrical properties of high-k material thin films

Fig 7. Part of periodic table. Illustrated in boldface are the elements which cations (with electronic structure of acti ve states in the second line), can combine with an anion (in italic) to form an insulating oxide.[7]

\begin{tabular}{|c|c|c|c|c|c|c|c|c|c|c|c|c|}
\hline IA & IIA & \multirow[b]{3}{*}{ IIIB } & \multirow[b]{3}{*}{ IVB } & \multirow[b]{3}{*}{ VB } & \multirow[b]{3}{*}{ VIE } & \multirow[b]{3}{*}{--} & \multirow[b]{3}{*}{ VII } & IIIA & IVA & \multicolumn{2}{|r|}{ VIA } & \multirow{2}{*}{$\frac{\text { VII }}{F}$} \\
\hline \begin{tabular}{|l|} 
Li \\
\end{tabular} & $\mathrm{Be}$ & & & & & & & $B$ & C & $\begin{array}{c}N \\
2 \mathrm{~s} 2 \mathrm{p}\end{array}$ & $\underset{2 s 2 p}{O}$ & \\
\hline $\mathrm{Na}$ & $\mathrm{Mg}$ & & & & & & & $\begin{array}{c}\text { Al } \\
\text { 3s3p }\end{array}$ & $\begin{array}{c}\text { Si } \\
\text { 3s3p }\end{array}$ & $P$ & $S$ & $\mathrm{Cl}$ \\
\hline K K & $\mathrm{Ca}$ & $\begin{array}{c}\text { Se } \\
3 \mathrm{~d} 4 \mathrm{~s}\end{array}$ & $\begin{array}{c}\mathbf{T i} \\
3 \mathrm{~d} 4 \mathrm{~s} \\
\end{array}$ & $\begin{array}{l}\mathrm{V} \\
\end{array}$ & $\mathrm{Cr}$ & & $\mathrm{Ni}$ & $\begin{array}{c}\text { Ga } \\
4 s 4 p\end{array}$ & Ge & As & $\mathrm{Se}$ & $\mathrm{Br}$ \\
\hline Rb & $\begin{array}{l}\text { Sr } \\
5 s \\
\end{array}$ & $\begin{array}{c}\mathbf{Y} \\
\text { 4d5s }\end{array}$ & $\begin{array}{c}\mathbf{Z r} \\
4 \mathrm{~d} 5 \mathrm{~s}\end{array}$ & $\begin{array}{c}\text { Nb } \\
\text { 4d5s }\end{array}$ & Mo & & $\mathrm{Pd}$ & $\ln$ & $\mathrm{Sn}$ & $\mathrm{Sb}$ & $\mathrm{Te}$ & I \\
\hline $\mathrm{Cs}$ & $\begin{array}{c}\text { Ba } \\
6 s \\
\end{array}$ & Lu & $\begin{array}{c}\text { Hff } \\
5 \mathrm{d \sigma 6}\end{array}$ & $\begin{array}{c}\text { Ta } \\
\text { 5d6s } \\
\end{array}$ & WV & & $\mathrm{Pt}$ & $\mathrm{Ti}$ & $\mathrm{Pb}$ & $\mathrm{Bi}$ & Po & At \\
\hline Fr & $\overline{\mathrm{Ra}}$ & ${ }^{*} \mathrm{Ca}$ & $\begin{array}{c}\text { Rf } \\
6 d 7 s\end{array}$ & $\overline{\mathrm{Db}}$ & $\overline{S g}$ & & & & & & & \\
\hline hth & des & $\underset{5 d 6 s}{\mathbf{L a}}$ & $\begin{array}{c}\text { Ce } \\
5 \mathrm{~d} 6 \mathrm{~s}\end{array}$ & $\begin{array}{c}\mathbf{P r} \\
\text { 5d6s }\end{array}$ & $\mathrm{Nd}$ & & \begin{tabular}{|c|} 
Gd \\
$5 \mathrm{~d} 6 \mathrm{~s}$
\end{tabular} & $\mathrm{Ho}$ & Er & $\mathrm{Tm}$ & $\mathrm{Yb}$ & \\
\hline cting & & & $\bar{\tau}$ & 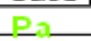 & ए1 & & & & & & & \\
\hline
\end{tabular}

Table-3 List of rapidly expanding material in CMOS technology [38-43]

\begin{tabular}{|l|l|l|l|l|l|l|}
\hline Material & $\begin{array}{l}\text { Dielectric } \\
\text { Constant } \\
(\mathbf{K})\end{array}$ & $\begin{array}{l}\text { Band gap } \\
\left(\mathbf{E}_{\mathbf{g}}\right)(\mathbf{e V})\end{array}$ & $\begin{array}{l}\text { Conduction } \\
\text { Band Offset } \\
\Delta \mathbf{E}_{\mathbf{c}}(\mathbf{e V})\end{array}$ & $\begin{array}{l}\text { Valence } \\
\text { Band Offset } \\
\Delta \mathbf{E}_{\mathbf{V}}(\mathbf{e V})\end{array}$ & $\begin{array}{l}\text { Stability } \\
\text { With } \mathbf{S i}\end{array}$ & $\begin{array}{l}\text { Crystal } \\
\mathbf{S t r u c t u r e}\end{array}$ \\
\hline Silicon & 3.9 & 8.9 & 3.5 & 4.4 & yes & Amorphous \\
\hline
\end{tabular}




\begin{tabular}{|c|c|c|c|c|c|c|}
\hline dioxide $\left(\mathrm{SiO}_{2}\right)$ & & & & & & \\
\hline $\begin{array}{l}\text { Silicon } \\
\text { nitride } \\
\left(\mathrm{Si}_{3} \mathrm{~N}_{4}\right)\end{array}$ & 7.0 & 5.1 & 2.4 & 1.8 & Yes & Amorphous \\
\hline $\begin{array}{l}\text { Aluminum } \\
\text { oxide }\left(\mathrm{Al}_{2} \mathrm{O}_{3}\right)\end{array}$ & 9.0 & 8.7 & 2.8 & 4.9 & Yes & Amorphous \\
\hline $\begin{array}{l}\text { Gadolinium } \\
\text { oxide } \\
\left(\mathbf{G d}_{2} \mathbf{O}_{3}\right) \\
\end{array}$ & 12 & 5.4 & 3.2 & 3.9 & Yes & Amorphous \\
\hline $\begin{array}{l}\text { Yattrium } \\
\text { oxide }\left(\mathrm{Y}_{2} \mathrm{O}_{3}\right)\end{array}$ & 15 & 5.6 & 2.3 & 2.6 & Yes & cubic \\
\hline $\begin{array}{l}\text { Zirconia } \\
\left(\mathrm{ZrO}_{2}\right)\end{array}$ & 25 & 7.8 & 1.4 & 3.3 & Yes & $\begin{array}{l}\text { Monoclinic, } \\
\text { cubic, } \\
\text { tetragonal }\end{array}$ \\
\hline $\begin{array}{l}\text { Tantulum } \\
\text { pentoxide } \\
\left(\mathrm{Ta}_{2} \mathrm{O}_{5}\right)\end{array}$ & 26 & 4.4 & 0.3 & 3.1 & No & orthorhombic \\
\hline $\begin{array}{l}\text { Hafnia } \\
\left(\mathrm{HfO}_{2}\right)\end{array}$ & 25 & 5.7 & 1.5 & 3.4 & Yes & $\begin{array}{l}\text { Monoclinic, } \\
\text { cubic, } \\
\text { tetragonal }\end{array}$ \\
\hline $\begin{array}{l}\text { Lanthana } \\
\left(\mathrm{La}_{2} \mathrm{O}_{3}\right)\end{array}$ & 30 & 6 & 2.3 & 0.9 & Yes & $\begin{array}{l}\text { Hexagonal, } \\
\text { cubic }\end{array}$ \\
\hline $\begin{array}{l}\text { Titanim oxide } \\
\left(\mathrm{TiO}_{2}\right)\end{array}$ & 80 & 3.5 & 1.2 & 1.2 & yes & Tetragonal \\
\hline $\begin{array}{l}\text { Strontium } \\
\text { titanate } \\
\left(\mathrm{SrTiO}_{3}\right)\end{array}$ & 300 & ? & & ? & no & cubic \\
\hline
\end{tabular}

Table 4- Comparisons of properties of hafnium, Zirconium, Titanium, \& Silicon Oxide, Gadolinium oxide , EOT calculated for oxide thickness of approximately $30 \mathrm{~nm}$ film. Electrical characteristics by considering $\mathrm{T}=300 \mathrm{~K}$, standard physical constant $(\mathrm{q}, \mathrm{K}, \mathrm{CO})$, electrode area $1 * 10^{-2} \mathrm{~cm}^{-2}$.

\begin{tabular}{|c|c|c|c|c|c|}
\hline Properties & $\mathrm{SiO}_{2}$ & $\mathrm{HfO}_{2}$ & $\mathrm{ZrO}_{2}$ & $\mathrm{TiO}_{2}$ & $\mathbf{G d}_{2} \mathbf{O}_{3}$ \\
\hline $\begin{array}{l}\text { Structure } \\
\text { Dielectric Constant } \\
\text { Band gap }(\mathrm{eV})\end{array}$ & $\begin{array}{c}\text { Amorphous } \\
\\
3.9 \\
8.9\end{array}$ & $\begin{array}{l}\text { Non- } \\
\text { crystalline } \\
20-25 \\
5.6\end{array}$ & $\begin{array}{c}\text { Nano-crystal } \\
\\
22-26 \\
4.7-5.7\end{array}$ & $\begin{array}{c}\text { Amorphous, Rutile } \\
22-40 \\
3.2\end{array}$ & $\begin{array}{c}\text { Amorophous } \\
\\
23 \\
5.4\end{array}$ \\
\hline $\begin{array}{l}\text { Technological } \\
\text { Formation Temp }\left({ }^{\circ} \mathrm{C}\right) \\
\text { Silicide formation } \\
\text { Thermal Stability }\end{array}$ & $\begin{array}{c}>700 \\
\text { NA } \\
1000\end{array}$ & $\begin{array}{l}350 \\
\text { Yes } \\
950\end{array}$ & $\begin{array}{l}350 \\
\text { Yes } \\
900\end{array}$ & $\begin{array}{l}400 \\
\text { NA } \\
550\end{array}$ & $\begin{array}{c}550 \\
\text { No } \\
1200\end{array}$ \\
\hline $\begin{array}{l}\text { Eectrical (approximat values) } \\
\text { Int erface trap density }\left(\mathrm{eV}^{-1} \mathrm{Cm}^{2}\right) \\
\text { Oxide trap density }\left(\mathrm{Cm}^{2}\right) \\
\text { Breakdown field }\left(\mathrm{MV} / \mathrm{Cm}^{2}\right) \\
\text { Capacitance }\left(\mathrm{C}_{\mathrm{ox}}\right) \mathrm{F} / \mathrm{Cm}^{2} \\
\text { Flat band voltage }\left(\mathrm{V}_{\mathrm{fb}}\right) \mathrm{V} \\
\text { Threshold Voltage }\left(\mathrm{V}_{\mathrm{t}}\right) \mathrm{V} \\
\text { Bulk Potential }\left(\emptyset_{f}\right) \\
\text { EOT nm } \\
\text { Low Leakage current density wrt } \\
\mathrm{SiO} 2\left(\mathrm{~A} / \mathrm{Cm}^{2}\right)\end{array}$ & $\begin{array}{c}10^{10} \\
10^{11} \\
10 \\
4.67 * 10^{9} \\
4.15 \\
4.9 \\
.30 \\
1100\end{array}$ & $\begin{array}{c}10^{12} \\
10^{12} \\
<4 \\
6.49^{*} 10^{-7} \\
0.85 \\
1.48 \\
.30 \\
35.45 \\
10^{4}-10^{5}\end{array}$ & $\begin{array}{c}10^{12} \\
10^{12} \\
<4 \\
6.79^{*} 10^{-7} \\
0.25 \\
0.88 \\
.30 \\
33.99 \\
10^{4}-10^{5}\end{array}$ & $\begin{array}{c}10^{12} \\
10^{12} \\
<4 \\
8.85^{*} 10^{-7} \\
.25 \\
.86 \\
.30 \\
31.15 \\
10^{1}-10^{2}\end{array}$ & $\begin{array}{c}10^{10} \\
10^{11} \\
3.5 \\
4.67 * 10^{-9} \\
.23 \\
.85 \\
.30 \\
33.74 \\
10^{2}-10^{3}\end{array}$ \\
\hline Properties & $\mathrm{SiO}_{2}$ & $\mathrm{HfO}_{2}$ & $\mathrm{ZrO}_{2}$ & $\mathrm{TiO}_{2}$ & $\mathbf{G d}_{2} \mathbf{O}_{3}$ \\
\hline $\begin{array}{l}\text { Structure } \\
\qquad \begin{array}{c}\text { Dielectric Constant } \\
\text { Band gap }(\mathrm{eV})\end{array}\end{array}$ & $\begin{array}{c}\text { Amorphous } \\
\\
3.9 \\
8.9\end{array}$ & $\begin{array}{c}\text { Non- } \\
\text { crystalline } \\
20-25 \\
5.6\end{array}$ & $\begin{array}{c}\text { Nano-crystal } \\
\\
22-26 \\
4.7-5.7\end{array}$ & $\begin{array}{c}\text { Amorphous, Rutile } \\
\\
22-40 \\
3.2\end{array}$ & $\begin{array}{c}\text { Amorophous } \\
\\
23 \\
5.4\end{array}$ \\
\hline
\end{tabular}




\begin{tabular}{|c|c|c|c|c|c|}
\hline $\begin{array}{l}\text { Technological } \\
\text { Formation Temp }\left({ }^{\circ} \mathrm{C}\right) \\
\text { Silicide formation } \\
\text { Thermal Stability }\end{array}$ & $\begin{array}{c}>700 \\
\text { NA } \\
1000\end{array}$ & $\begin{array}{l}350 \\
\text { Yes } \\
950\end{array}$ & $\begin{array}{l}350 \\
\text { Yes } \\
900\end{array}$ & $\begin{array}{l}400 \\
\text { NA } \\
550\end{array}$ & $\begin{array}{c}550 \\
\text { No } \\
1200\end{array}$ \\
\hline $\begin{array}{c}\text { Breakdown field }(\mathrm{MV} / \mathrm{Cm}) \\
\text { Capacitance }\left(\mathrm{C}_{\mathrm{ox}}\right) \mathrm{F} / \mathrm{Cm}^{2} \\
\text { Flat band voltage }\left(\mathrm{V}_{\mathrm{fb}}\right) \mathrm{V} \\
\text { Threshold Voltage }\left(\mathrm{V}_{\mathrm{t}}\right) \mathrm{V} \\
\text { Bulk Potential }\left(\dot{\emptyset}_{\mathrm{f}}\right) \\
\text { EOT nm } \\
\text { Low Leakage current density wrt } \\
\mathrm{SiO} 2\left(\mathrm{~A} / \mathrm{Cm}^{2}\right)\end{array}$ & $\begin{array}{c}10^{10} \\
10^{11} \\
10 \\
4.67 * 10^{-9} \\
4.15 \\
4.9 \\
.30 \\
1100\end{array}$ & $\begin{array}{c}10^{12} \\
10^{12} \\
<4 \\
6.49^{*} 10^{-7} \\
0.85 \\
1.48 \\
.30 \\
35.45 \\
10^{4}-10^{5}\end{array}$ & $\begin{array}{c}10^{12} \\
10^{12} \\
<4 \\
6.79^{*} 10^{-7} \\
0.25 \\
0.88 \\
.30 \\
33.99 \\
10^{4}-10^{5}\end{array}$ & $\begin{array}{c}10^{12} \\
10^{12} \\
<4 \\
8.85^{*} 10^{-7} \\
.25 \\
.86 \\
.30 \\
31.15 \\
10^{1}-10^{2}\end{array}$ & $\begin{array}{c}10^{10} \\
10^{11} \\
3.5 \\
4.67 * 10^{9} \\
.23 \\
.85 \\
.30 \\
33.74 \\
10^{2}-10^{3}\end{array}$ \\
\hline
\end{tabular}

Table-5 comparison of various MOS capacitor with different dielectric material and their leakage currents [34,50]

\begin{tabular}{|c|c|c|c|c|}
\hline Capacitor & Gate dielectric & $\begin{array}{c}\text { Dielectric } \\
\text { constant }\end{array}$ & EO T(nm) & $\begin{array}{c}\text { Leakage current density } \\
\text { V= 1V(A/Cm }\end{array}$ \\
\hline $\mathbf{1}$ & $\mathrm{TiO}_{2}(58 \mathrm{~nm})$ & 40 & 5 & 0.07 \\
\hline $\mathbf{2}$ & $\mathrm{TiO}_{2}(58 \mathrm{~nm}) / \mathrm{SiO}_{2}(6 \mathrm{~nm})$ & 20 & 12 & $4.7 \times 10^{-6}$ \\
\hline $\mathbf{3}$ & $\mathrm{SiO}_{2}$ thermally grown grown & 3.9 & 5 & $<10^{-9}$ \\
\hline $\mathbf{4}$ & $\mathrm{SiO}_{2}(49 \mathrm{~nm})$ & 3.9 & 49 & $1.3 \times 10^{-8}$ \\
\hline $\mathbf{5}$ & $\mathrm{Gd}_{2} \mathrm{O}_{3}(15 \mathrm{~nm})$ & 23 & 2.3 & $3.6 \times 10^{-5}$ \\
\hline $\mathbf{6}$ & $\mathrm{ZrO} 2$ & 7 & & $3.25 \times 10^{-5}$ \\
\hline $\mathbf{7}$ & $\mathrm{HfO} 2$ & 10 & & $4.1 \times 10^{-0}$ \\
\hline
\end{tabular}

\section{CONCLUSION:}

The high-K alone can't be a feasible solution for future CMOS technology. System on Chip (SoC) and System in Package (SiP) technologies provide a path for continous improvement in performance, power, cost and size at the system level. As we have reached the below $.7 \mathrm{~nm}$ in scaling. So it is difficult to continue with the historical trend of scaling. So there is need of innovations in the field of advanced material, non planar device structure, process control, manufacturability, and leakage current. To continue the conventional path of scaling there is need high-K material with suppressed tunneling current, higher channel doping for reducing short channel effects, trade off between mobility degradation and increased leakage power consumptions. The scaling below $16 \mathrm{~nm}$ is attainable by alternate to replace $\mathrm{Si}$ and alternate to replace new information technology to replace CMOS. The $\mathrm{La}_{2} \mathrm{O}_{3}$ have serious reliability problems for the actual application for MOS gate dielectric. It can also be concluded that the $\mathrm{Gd}_{2} \mathrm{O}_{3}$ films grown by magnetron sputtering may be promising candidate as high-K gate dielectric in CMOS devices. Hafnium oxide and Zirconium oxide have shown much promising properties to replace $\mathrm{SiO}_{2}$. $\mathrm{TiO}_{2}$ and other high-k material have basic problem is variation in threshold voltage due to both oxide traps and interface trap generations. So it can be concluded that the high-k materials, along with the right process recipe, may reduce gate leakage, for delivering expected transistor performance.

\section{REFERENCES:}

[1] D.Rathee, et al, proc. Of National Conference ITM, oct6(2007)82-87

[2] G.Moore, IEDM Tech., Dig. (1975)

[3] H.Iwai, Hei Wong, Microelectronics Engg. 83(2006) 1867-1904

[4] http://www.itrs.net

[5] B. Doris, et al, IEDM Tech Dig. (2002) 267.

[6] H.S.P Wong, et al, Proc. IEEE 87 (1999) 537

[7] D.Frenk, et al, Proc. IEEE 89 (2001) 259.

[8] H.Iwai Microelectronics Engg. 86(2009), 1520-1528.

[9] Sidda Reddy Kurakulla, M.S in Engg. Thesis, IIS Banglore, oct $27,2007$.

[10] ITRS 2003, Edition, Semiconductor Industry Association (SIA), Austin, SEMATECH USA, 2706 from :http://www.itrs.net/ntrs/publntrs.nsf

[11] R Chau, et al, IEEE Electron Device Letter, 25 (2004) 408

[12] D.Mullar, et al, Nature, 758(1999) 399

[13] M. Radder, et al, IEDM technical Digest, (1998) 623.

[14] H.Iwai, Hei Wong, Microelectronics Engg. 83(2006) 1867-1904.

[15] H.Iwai, Sc in IEDM,2008.

[16] H.Wong, V.A.Gitsenko, Microelectron. Reliab 42(2002)597.

[17] K.Tse, et al, Microelectron Engg. 84(2007)2028.

[18] S.H.Lo, et al, IEEE Electron devices lett. 18 (1997) 209. 
[19] G.D. Wick, et al, J. of App. Phy 89 (2001) 5243

[20] D.Buchanan, IBM J.Res Develop 43(1999) 245

[21] L.Manchanda, et al, Idem Technical Digest (1998) 605.

[22] E.P.Gusev, et al, Appl. Phy lett 76(2000) 176.

[23] M.Copel, et al, Appl. Phy lett 78(2001)2670.

[24] D.A. Buchanan, et al, IEDM technical digest (2000)

[25] R.Ludeka, et al, Appl. Phy lett 76 (2001)2886

[26] M.Coepl, et al, Appl. Phy lett 76(2000)436

[27] T.S.Jeon, et al, Appl. Phy lett 78(2001)368

[28] W.J, et al, Appl. Phy lett 77(2000)3269.

[29] L. kang, et al, IEDM technical Digest (2000)181

[30] T.Modes, et al, Surf and coat Tech, 200 (2005)306

[31] Sin-iti Kitazawa, et al, Thin Solid Films 515 (2006) 1901.

[32] S.Murugesan, et al, Surf and Coat Tech, 201 (2007) 7713

[33] Shoujing, et al, jounal of physics series, 152 (2009) 012004

[34] D. Buchanan, IBM J.Res\Develop 43(1999)245

[35] A.M. Stoneham, Journal of Non-crystlline Solids 303 (2002) 114-122

[36] Sin-iti Kitazawa, et al, Thin Solid Films 515 (2006) 1901
[37] D. Buchanan, IBM J.Res\Develop 43(1999)245

[38] C.Kittel, Introduction to solid state physics $7^{\text {th }}$ edition, john wiely \& sons Inc New York (1996)

[39] G.D. Wilk, et al, J Appl Phy 89 (2001) 5243

[40] J.Rebertson, J Vac Sci B 18 (2000) 1785

[41] K Hubbard, D Sehlon, J Matr Reg 11 (1996) 2757

[42] Ep Gusev, et al, Appl phy letter 76 (2000) 176

[43] G.Lucovsky, et al, springer US (2002) 189.

[44] T.Modes, et al, Surf and coat Tech, 200 (2005)306

[45] Sin-iti Kitazawa, et al, Thin Solid Films 515 (2006) 1901.

[46] S.Murugesan, et al, Surf and Coat Tech, 201 (2007) 7713

[47] E.K.Evan gelou, et al, J Applphy 94 (2003) 318

[48] E.P.Gusev, et al, IBM research, Microelectronics engg.,59 (2001) 341

[49] Anieszka Borkowska, et al, workshop "Photnic and Microsy stem'IEEE (2006).

[50] K.F. Albertin, et al, Journal of circuits and system v2n2 (2007) 89-93

[51] Banani Sen, et al, Solid State Electronics 51 (2007) 475-480

[52] Martin M Frank, et al, Microelectronics Engg. 86 (2009). 